DOI: $10.19195 / 2084-5065.48 .3$

\title{
Uwagi o istocie przestępstwa o charakterze terrorystycznym i jego karaniu. Część I
}

\author{
RAJNHARDT KOKOT \\ ORCID: 0000-0002-6240-7282 \\ Katedra Prawa Karnego Materialnego \\ Wydział Prawa, Administracji i Ekonomii Uniwersytetu Wrocławskiego
}

Przestępstwo o charakterze terrorystycznym jako pojęcie jurydyczne, mimo kryminalnej doniosłości zjawiska terroryzmu i jego długiej obecności w przestrzeni społecznej, nie legitymuje się w rodzimym systemie prawnym imponującą metryką. Pomimo iż zagrożenia z nim związane na gruncie polskiej nauki prawa karnego dostrzeżone zostały już w pierwszych dekadach XX wieku, dopiero początek wieku XXI przyniósł rozwiązania prawne odnoszące się wprost do jego istoty i prawnokarnych następstw. $Z$ tej perspektywy intrygować może opieszałość polskiego ustawodawcy $\mathrm{i}$ wieloletni brak normatywnej reakcji na to zjawisko, a zwłaszcza przyczyny takiego stanu rzeczy. Stan ten rodzi jednocześnie pytania, jak system prawny radził sobie z zamachami o charakterze terrorystycznym i czy wobec tego nieodzowne były zmiany w normatywnym podejściu do tej kategorii przestępstw. Wśród zagadnień, które znalazły się $\mathrm{w}$ zakresie niniejszego opracowania, jako szczególnie interesujące jawią się kwestie związane z genezą i ewolucją jurydycznego ujęcia zamachów terrorystycznych w polskim prawie karnym. Artykuł koncentruje się na wybranych wątkach normatywnej konstrukcji przestępstwa terrorystycznego, jego charakterze prawnym, a także konsekwencjach 
w sferze stosowania omawianych unormowań. Pominięte zostały w nim natomiast niewątpliwie bardzo istotne dla analizy tego zjawiska zagadnienia strony podmiotowej przestępstwa o charakterze terrorystycznym, którym poświęcone zostało odrębne opracowanie ${ }^{1}$. Dopełnieniem tych rozważań są uwagi dotyczące następstw przestępstwa terrorystycznego na płaszczyźnie wymiaru kary, zarówno ustawowego, jak i sądowego.

W ustawodawstwie karnym okresu międzywojennego brakowało normatywnej definicji przestępstwa terrorystycznego. System prawny całkowicie zresztą pomijał problematykę terroryzmu. Przestępstwa mające taki charakter z perspektywy obowiązujących unormowań były więc traktowane na ogólnych zasadach, z możliwością uwzględnienia szczególnie nagannych okoliczności przedmiotowych i elementów intencyjnych w wymiarze kary ${ }^{2}$. Problem tego rodzaju zachowań był jednak przez przedstawicieli doktryny dostrzegany, a istniejący stan normatywny uznawany za niewystarczający. Deficyt unormowań w tym zakresie prowadził do formułowania postulatów autonomicznego uregulowania zachowań „motywowanych terrorystycznie”. Jedną ze znaczących prób idących w tym kierunku była sformułowana przez Rafała Lemkina w 1935 roku propozycja stworzenia zbrodni „nowego typu”3. Punkt wyjścia jego koncepcji stanowiła ogólna, szeroka definicja terroryzmu, w której wyeksponowany został element subiektywny. Akt terrorystyczny, czy po prostu przestępstwo terrorystyczne, R. Lemkin określał jako „zastraszanie ludzi za pomocą czynów gwałtownych”4. Propozycja ta zakładała wprowadzenie do kodeksu karnego z 1932 roku autonomicznych typów przestępstw regulujących akty terroryzmu. W zaproponowanych rozwiązaniach, wnikliwie diagnozując charakter, naturę i skalę

${ }^{1}$ Por. R. Kokot, Z problematyki strony podmiotowej przestepstwa o charakterze terrorystycznym, [w:] O stabilność kodeksu karnego w świetle realiów. Księga Jubileuszowa prof. zw. dra hab. Stanisława Hoca, t. 1, red. D. Mucha, Opole 2018, s. 227 n.

${ }^{2}$ W grę wchodziły zwłaszcza przestępstwa określone w art. 125-133, skierowane przeciwko władzom i urzędom, lecz także czyny zabronione stypizowane w art. 93-95 (zbrodnie stanu), art. 111 (czynna napaść na naczelnika lub przedstawiciela dyplomatycznego obcego państwa), art. 215-217 (sprowadzenie bezpośredniego niebezpieczeństwa), art. 225 oraz art. 235-237 (zamachy na życie lub zdrowie) czy art. 250-251 (zamachy na wolność) kodeksu karnego z 1932 roku.

3 R. Lemkin, Terroryzm, „Gazeta Sądowa Warszawska” 1935, nr 41, s. 561 n.

4 Ibidem. 
zjawiska, R. Lemkin przyjął dystynkcję zachowań terrorystycznych na terroryzm wewnętrzny i międzynarodowy. Przedmiotem ochrony zbrodni terroryzmu był odpowiednio: w przypadku terroryzmu wewnętrznego „porządek publiczny”, natomiast w odniesieniu do terroryzmu międzynarodowego — „międzynarodowy porządek publiczny”5. Koncepcja R. Lemkina zakładająca potrzebę normatywnego ujęcia zjawiska terroryzmu i penalizację jej przejawów nie zyskała jednak szerszego poparcia w rodzimym środowisku prawniczym. Paradoksalnie, jej założenia znacznie wyraźniej rezonowały w nauce europejskiej, w której stanowiły istotny głos w toczącej się wówczas dyskusji nad przyszłością walki $\mathrm{z}$ terroryzmem na gruncie unormowań prawnych, o charakterze zarówno międzynarodowym, jak i krajowym. Problematyka przestępstwa terrorystycznego w znaczeniu, jakie przypisywał mu R. Lemkin, w ciągu następnych pięciu dekad nie znalazła się w głównym nurcie zainteresowań polskiego piśmiennictwa karnistycznego. W ówczesnej nauce prawa karnego, także po zmianie kodeksu karnego, swoją obecność mocno zaznaczył pogląd, iż wprowadzenie do porządku prawnego ogólnej i szerokiej konstrukcji przestępstwa terrorystycznego nie jest nie tylko nieodzowne, lecz wręcz zbędne. Stanowisko to argumentowano przede wszystkim tym, iż zadanie swoje w tym zakresie znakomicie realizują zwłaszcza stypizowane $\mathrm{w}$ ustawie przestępstwa przeciwko bezpieczeństwu powszechnemu i bezpieczeństwu w komunikacji, za które polskie prawo karne przewiduje bardzo surowe sankcje, pozwalając na pełną indywidualizację dolegliwości karnej, także w odniesieniu do zamachów szczególnie społecznie niebezpiecznych, w tym mających charakter terrorystyczny ${ }^{6}$.

Zmiany społeczne, ekonomiczne i polityczne, jakie nastąpiły w Polsce po drugiej wojnie światowej, pojęciu „akt terrorystyczny” nadały zupełnie nowe znaczenie. Nowa koncepcja zbrodni terrorystycznej odchodziła od niezrealizowanej w okresie międzywojennym szerokiej wizji tego przestępstwa. Zamachy terrorystyczne przyjęły konstrukcję „terroru politycznego"7. Ich typizacja miała wyraźne podłoże ideologiczne i poli-

5 Ibidem, s. 561-562.

6 J. Śliwowski, Odpowiedzialność karna za akty terroryzmu z uwzględnieniem norm polskiego prawa karnego, „Problemy Praworządności” 1975, nr 2, s. 22-23.

7 A. Krukowski, [w:] System prawa karnego, t. 4. O przestepstwach w szczególności, Wrocław-Warszawa-Kraków-Gdańsk-Łódź 1985, s. 68. 
tyczne, a jej podstawowym celem była walka z „kontrrewolucją”. Zarzut dopuszczenia się czynu zabronionego o charakterze terrorystycznym stał się tym samym jednym $\mathrm{z}$ instrumentów walki prowadzonej z polityczną opozycją ${ }^{8}$. Kodeks karny z 1969 roku ,zamach terrorystyczny” określał w analogicznie politycznym wymiarze, jak czyniło to powojenne ustawodawstwo przedkodeksowe. Typizujący go art. 126 - recypujący zasadnicze założenia konstrukcji zbrodni zamachu terrorystycznego, określonej w art. 1 „małego kodeksu karnego” — umieszczony został w rozdziale regulującym przestępstwa przeciwko podstawowym interesom politycznym i gospodarczym państwa. Pojęcie zamachu terrorystycznego stanowiło jednak wciąż jedynie termin prawniczy, a nie prawny ${ }^{9}$. Zbrodnię tę popełniał ten, jak stanowił $\S 1$ tego przepisu, ,kto w celu wrogim Polskiej Rzeczypospolitej Ludowej dopuszcza się gwałtownego zamachu na życie funkcjonariusza publicznego lub działacza politycznego". W stosunku do poprzedniej regulacji zakres podmiotów, których dobra osobiste były obocznie chronione $\mathrm{z}$,bezpieczeństwem wewnętrznym”, został istotnie poszerzony. Zamach terrorystyczny w rozumieniu art. 126 należał do kategorii przestępstw kierunkowych. Działanie „w celu wrogim” mogło więc być zrealizowane jedynie w warunkach zamiaru o szczególnym zabarwieniu motywacyjnym (dolus coloratus $)^{10}$. W doktrynie tego okresu, poza zbrodnią stypizowaną w art. 126, do kategorii przestępstw „o podłożu terrorystycznym” powszechnie zaliczane było także przestępstwo sabotażu stypizowane w art. 127 k.k. z 1969 roku. Zagrożone było analogicznie jak zamach stricte terrorystyczny z art. 126 k.k. surową sankcją — włącznie z karą śmierci. Taki charakter, zważywszy na ustawowe znamiona, w tym zwłaszcza przedmiot ochrony czy modus operandi, mogły

8 Zachowania tego rodzaju zostały unormowane już w dekrecie o ochronie państwa z 3 października 1944 r. (art. 3), a następnie w dekrecie z 15 listopada 1945 r. o przestępstwach szczególnie niebezpiecznych w okresie odbudowy państwa (art. 1). Regulację tę przejął następnie tzw. mały kodeks karny — dekret z 13 czerwca 1946 r. o przestępstwach szczególnie niebezpiecznych w okresie odbudowy Państwa (Dz.U. nr 30, poz. 192).

9 Por. K. Buchała, Prawo karne materialne, Warszawa 1989, s. 602; H. Popławski, Przestęstwa przeciwko podstawowym interesom politycznym PRL, Warszawa-Poznań 1989, s. 161; W. Świda, Prawo karne, Warszawa 1989, s. 394; S. Pikulski, Karnomaterialne, kryminologiczne i kryminalistyczne aspekty terroryzmu, WPP 1991, nr 3-4, s. 29.

10 J. Śliwowski, Prawo karne, Warszawa 1975, s. 337. 
też mieć przestępstwa określone w art. 136, 137, 142, a także przestępstwa przeciwko życiu i zdrowiu (art. 148, 156-157) oraz niektóre przestępstwa przeciwko wolności (art. 165-167) określone w tym kodeksie. Warto zauważyć, iż zamachy terrorystyczne w znaczeniu, jakim posługiwał się R. Lemkin i jakie przypisuje się im współcześnie, nie były w Polsce Ludowej - na tle państw Europy Zachodniej — zjawiskiem zbyt częstym, a te, $\mathrm{z}$ reguły o indywidualnym charakterze, które miały w tym czasie miejsce — w tym zwłaszcza uprowadzenia samolotów używanych do ucieczki z kraju (tzw. terroryzm lotniczy) lub motywowane politycznie zamachy na prominentnych polityków (np. B. Bieruta, W. Gomułkę) bądź obiekty publiczne (np. aula WSP w Opolu) — były przez ówczesną władzę skrzętnie skrywane lub traktowane jako przestępczość pospolita. Terroryzm w Polsce Ludowej był więc — w pewnym sensie — zjawiskiem dla władzy wstydliwym i dlatego nieeksponowanym medialnie, a nawet utajnianym, bo jako zjawiska o wyraźnie, a właściwie wyłącznie, politycznym profilu jego obecność wskazywała na niezadowolenie społeczne, a tym samym podważała pozycję władzy, uderzając w kreowany przez nią obraz pełnego poparcia i akceptacji społecznej. Sprawcy takich działań ponosili odpowiedzialność na zasadach ogólnych na podstawie przepisów, których znamiona in concreto zostały wyczerpane, przy czym ich ,polityczna” motywacja wpływała istotnie obostrzająco na sądowy wymiar kary ${ }^{11}$.

Kodeks karny z 1997 roku w wersji pierwotnie uchwalonej nie regulował problematyki przestępstwa terrorystycznego. Nie oznacza to wszakże, iż zachowania motywowane celami właściwymi działaniom o charakterze terrorystycznym pozostawały bez możliwości adekwatnej prawnokarnej reakcji. Ten rodzaj strony podmiotowej, gdy towarzyszył realizacji znamion przestępstw, których konstrukcja nadawała się do realizacji „celów terrorystycznych" ${ }^{2}$, mógł być jednak uwzględniany do-

11 Szerzej na temat „ukrywanego oblicza” rodzimego terroryzmu lat sześćdziesiątych, siedemdziesiątych i osiemdziesiątych, jego form i przypadków - W. Zarzycki, Terroryzm w Polsce, „Palestra” 1992, nr 11-12, s. 45 n.; por. też S. Pikulski, Prawne środki zwalczania terroryzmu, Olsztyn 2000, s. 105-107.

12 Do realizacji ,celów terrorystycznych” nadawały się w szczególności przestępstwa przeciwko: pokojowi, ludzkości oraz przestępstwa wojenne (rozdział XVI), Rzeczypospolitej Polskiej (rozdział XVII), obronności (rozdział XVIII), życiu i zdrowiu 
piero w toku sądowego wymiaru kary jako okoliczność obciążająca ${ }^{13}$. W kodeksie karnym z 1997 roku znalazły się jednak także nowe, nieznane poprzedniej kodyfikacji, typy czynów zabronionych, których normatywna natura wynikająca zwłaszcza ze strony podmiotowej oraz modus operandi czyniła z nich szczególne instrumenty w walce z przestępczością o charakterze terrorystycznym. Do tej kategorii należałoby zaliczyć w szczególności przestępstwa przeciwko bezpieczeństwu powszechnemu, stypizowane w art. 166 k.k. i 167 k.k., na co wprost zwracało uwagę uzasadnienie projektu ${ }^{14}$, przestępstwo wzięcia zakładnika z art. 252 k.k., a także kwalifikowane postaci zabójstwa, w tym zwłaszcza popełnione przy użyciu broni palnej lub materiałów wybuchowych (art. 148 § 2 pkt 4 k.k.), w związku z wzięciem zakładnika (art. 148 § 2 pkt 2 k.k.) oraz zabójstwo jednym czynem więcej niż jednej osoby (art. 148 § 3 k.k.). Również przepisy odnoszące się do przestępczości zorganizowanej (art. 258 k.k.), w tym skutków dopuszczenia się przestępstwa w takich warunkach (art. 65 k.k.), mogły znaleźć zastosowanie w odniesieniu do przestępczości terrorystycznej. Przestępstwo terrorystyczne wprost w ustawie tej nie zostało jednak określone. Stan deficytu w tym zakresie powodował, iż postulat kryminalizacji terroryzmu w ustawie karnej oraz określenia surowych zasad odpowiedzialności za akty terrorystyczne był w piśmiennictwie wielokrotnie formułowany ${ }^{15}$. Zgodnie przy tym przyjmowano, iż wyodrębnienie przestępstwa terrorystycznego jako typu czynu zabronionego — zbrodni terroryzmu — nie jest rzeczą łatwą, jeśli

(rozdział XIX), bezpieczeństwu powszechnemu (rozdział XX), bezpieczeństwu w komunikacji (rozdział XXI), wolności (rozdział XXIII), działalności instytucji państwowych oraz samorządowych (rozdział XXIX), wymiarowi sprawiedliwości (rozdział XXX), porządkowi publicznemu (rozdział XXXII), ochronie informacji (rozdział XXXIII) oraz mieniu (rozdział XXXV).

13 Por. M. Filar, Terroryzm - problemy definicyjne oraz regulacje prawne $w$ polskim prawie karnym $w$ świetle prawa międzynarodowego i porównawczego, [w:] Terroryzm. Materiały z sesji naukowej, red. V. Kwiatkowska-Darul, Toruń 2002, s. 27 n.; C. Sońta, Przestepstwo o charakterze terrorystycznym w prawie polskim, WPP 2005, nr 4, s. 8.

14 Nowe kodeksy karne - z 1997 r. z uzasadnieniami, Warszawa 1997, s. 188.

15 Por. na przykład K. Indecki, Kryminalizacja aktu terrorystycznego — zagadnienia wybrane, „Acta Universitatis Lodziensis, Folia Iuridica” 67, 2004, s. 21 n.; K. Daszkiewicz, Terroryzm znów staje się zbrodnia, ,,Rzeczpospolita” 25 września 2001 r.; L. Gardocki, Terroryzm wymusza zmiane przepisów, „Rzeczpospolita” 26 listopada 2001 r. 
w ogóle możliwą. Zbyt wiele bowiem dóbr prawnych może być przedmiotem zamachu o takim charakterze ${ }^{16}$.

Pojęcie przestępstwa o charakterze terrorystycznym jako termin ustawowy pojawiło się po raz pierwszy w polskim ustawodawstwie karnym wraz z nowelizacją kodeksu karnego z 16 kwietnia 2004 roku, która ze względu na przedmiot regulacji w piśmiennictwie określana jest mianem „noweli antyterrorystycznej”" ${ }^{17}$. Wprowadziła ona zarówno legalną definicję przestępstwa o charakterze terrorystycznym, jak i określiła jego szczególne konsekwencje na płaszczyźnie wymiaru kary ${ }^{18}$. Do tej chwili pojęcia przestępstwa terrorystycznego, zamachu terrorystycznego czy przestępstwa o charakterze terrorystycznym funkcjonowały w nauce prawa karnego jedynie jako terminy prawnicze, a przypisywane im treści były tyleż nieuporządkowane, ile intuicyjne ${ }^{19}$. Ustanowienie definicji legalnej przestępstwa o charakterze terrorystycznym było jednym ze środków dostosowania polskiego prawa karnego do standardów unijnych, przyjętych w latach 2001-2002 w ramach dorobku prawnego Unii Europejskiej. Jednym z kierunków standaryzacji prawa karnego państw unijnych stała się potrzeba implementacji rozwiązań prawnych dotyczących

16 K. Daszkiewicz, op. cit.; K. Indecki, op. cit., s. 24-25.

17 Ustawa z 16 kwietnia 2004 r. o zmianie ustawy — Kodeks karny oraz niektórych innych ustaw, Dz.U. z 2004 r. Nr 93, poz. 889, weszła w życie 1 maja 2004 roku. Por. K. Wiak, Przestępstwa o charakterze terrorystycznym i ich konsekwencje w świetle przepisów kodeksu karnego, [w:] Zmiany w polskim prawie karnym po wejściu w życie kodeksu karnego z 1997 r., red. T. Bojarski et al., Lublin 2006, s. 314; C. Sońta, op. cit., s. 4.

18 Jej moca, poza wprowadzeniem art. $115 \S 20$ k.k. (definicja przestępstwa o charakterze terrorystycznym) oraz zmianą brzmienia art. 65 k.k. (nadzwyczajne obostrzenie kary wobec sprawcy przestępstwa o charakterze terrorystycznym), znowelizowano także art. $110 \S 1$ k.k. (odpowiedzialność cudzoziemca za popełnione za granicą przestępstwo o charakterze terrorystycznym), a także art. $258 \S 2$ i 4 k.k. (kwalifikowane typy przestępstw udziału w grupie lub związku mających na celu popełnienie przestępstwa o charakterze terrorystycznym oraz zakładanie lub kierowanie taką grupą lub związkiem).

${ }^{19}$ Wprawdzie przepisy karne pojęciami tymi się nie posługiwały, jednak w licznych aktach prawnych używano określenia ,terroryzm” nierzadko w kontekście nawiązującym nie tylko do ogólnego pojęcia zjawiska niosącego szczególne zagrożenie społeczne, lecz także aktów czy czynów będących wyrazem urzeczywistnienia tych zagrożeń. Pojęcie „terroryzm” występowało w nich z reguły jako jeden z celów rozpoznawania, zapobiegania i wykrywania, należących do ustawowych zadań i kompetencji właściwych organów i służb. 
przestępstw terrorystycznych. Zobowiązanie do korektury, czy też ściślej uzupełnienia wewnętrznego porządku prawnego, wynikało wprost z decyzji ramowej Rady Unii Europejskiej z 13 czerwca 2002 roku w sprawie zwalczania terroryzmu ${ }^{20}$, która obligowała państwa członkowskie oraz państwa aspirujące do członkostwa w Unii do przyjęcia ,zbliżonej definicji przestępstw terrorystycznych". Pojęcie przestępstw o charakterze terrorystycznym określał art. 1 ust. 1 decyzji ramowej, zgodnie z którym były nimi ,,przestępstwa, które ze względu na swój charakter i kontekst mogą wyrządzić poważne szkody krajowi lub organizacji międzynarodowej”, charakteryzujące się określoną treścią intencyjną - celami działania - oraz rodzajem naruszonych dóbr prawnych ${ }^{21}$. Decyzja ramowa

20 Decyzja Ramowa Rady Unii Europejskiej 2002/475/WSiSW (Dz. Urz. WE L 164 z 22 czerwca 2002 r.). Szerzej na ten temat K. Wiak, Prawnokarne środki przeciwdziałania terroryzmowi, Lublin 2009, s. 189 n.; S. Hoc, Nowe prawo Unii Europejskiej w sprawie zwalczania terroryzmu, [w:] Między stabilnościa a zmiennościa prawa karnego. Dylematy ustawodawcy, red. W. Cieślak, M. Romańczuk-Grącka, Olsztyn 2017, s. 349 n.; M. Szwarc, Decyzje ramowe jako instrument harmonizacji prawa karnego w UE, PiP 2005, z. 7.

21 Definicja przestępstwa terrorystycznego, przyjęta w decyzji ramowej, miała charakter segmentowy. Przestępstwo to dookreślone zostało na podstawie dwu kryteriów - celu działania oraz charakteru przestępstwa determinowanego rodzajem dobra prawnego, w które zamach godzi. Kryterium szczególnego celu działania sprawcy przestępstwa o charakterze terrorystycznym określone zostało w sposób alternatywny. Musiał nim być co najmniej jeden z następujących celów: 1. poważne zastraszenie ludności, 2. bezprawne zmuszenie rządu lub organizacji międzynarodowej do podjęcia lub zaniechania działania, 3. poważna destabilizacja lub zniszczenie podstawowych politycznych, konstytucyjnych, gospodarczych lub społecznych struktur kraju lub organizacji międzynarodowej. Decyzja ramowa za przestępstwa terrorystyczne uznała motywowane w ten sposób: 1. ataki na życie ludzkie, które mogą powodować śmierć; 2. ataki na integralność cielesną osoby; 3. porwania lub branie zakładników; 4. spowodowanie rozległych zniszczeń obiektów rządowych lub obiektów użyteczności publicznej, systemu transportowego, infrastruktury, włącznie ze zniszczeniem systemu informacyjnego, stałych platform umieszczonych na szelfie kontynentalnym, miejsca publicznego lub mienia prywatnego, mogące zagrozić życiu ludzkiemu lub mogące spowodować poważne straty gospodarcze; 5. zajęcie statku powietrznego, statku lub innego środka transportu publicznego lub towarowego; 6. wytwarzanie, posiadanie, nabywanie, przewożenie, dostarczanie lub używanie broni, materiałów wybuchowych lub jądrowych, broni biologicznej lub chemicznej, jak również badania i rozwój broni biologicznej i chemicznej; 7. uwalnianie substancji niebezpiecznych lub powodowanie pożarów, powodzi lub wybuchów, których rezultatem jest zagrożenie życia ludzkiego; 8. zakłócenia lub przerwy w dostawach wody, energii

Nowa Kodyfikacja Prawa Karnego 48, 2018

(C) for this edition by CNS 
Rady zobowiązywała jednocześnie do określenia następstw prawnych w zakresie wymiaru kary, odzwierciedlających poważny charakter tej kategorii przestępstw (art. 5 ust. 1-3).

Jak wynika z dodanego mocą nowelizacji z 16 kwietnia 2004 roku art. $115 \S 20$ k.k., przestępstwem mającym charakter terrorystyczny jest „czyn zabroniony zagrożony karą pozbawienia wolności, której górna granica wynosi co najmniej 5 lat, popełniony w celu: 1) poważnego zastraszenia wielu osób, 2) zmuszenia organu władzy publicznej Rzeczypospolitej Polskiej lub innego państwa albo organu organizacji międzynarodowej do podjęcia lub zaniechania określonych czynności, 3) wywołania poważnych zakłóceń w ustroju lub gospodarce Rzeczypospolitej Polskiej, innego państwa lub organizacji międzynarodowej - a także groźba popełnienia takiego czynu". Jak z tego wynika, przestępstwo to występuje w dwóch odmianach: jako popełnienie czynu zabronionego w jednym ze wskazanych w ustawie celów oraz jako groźba popełnienia takiego czynu. Podstawowym następstwem popełnienia przestępstwa o charakterze terrorystycznym jest wynikające $\mathrm{z}$ art. $65 \S 1$ k.k. nadzwyczajne obostrzenie kary opierające się na regułach jej wymiaru właściwych recydywie wielokrotnej i innym formom przestępczości szczególnie niebezpiecznej.

Przestępstwo o charakterze terrorystycznym, określone w art. 115 $\S 20$ k.k., wymyka się klasycznym regułom typizacji czynu zabronionego. Ustawodawca nie wskazuje w konstrukcji przepisu ani znamienia czasownikowego oddającego sposób zachowania sprawcy, ani choćby minimum przedmiotowych cech charakterystycznych dla tego przestępstwa, w tym znamienia przemocy stanowiącego powszechnie wskazywany znak rozpoznawczy zachowań o charakterze terrorystycznym. Przepis ten nie określa też następstw popełnienia takiego przestępstwa. Artykuł $115 \S 20$ k.k. — mający z racji odwołania się do szerokiego katalogu przestępstw zagrożonych karą co najmniej 5 lat pozbawienia wolności „charakter blankietowy” - dookreśla natomiast i definiuje podmiotową specyfikę określonej w nim kategorii przestępstw, będąc w rzeczy samej jedynie - jak stwierdza K. Indecki — „zbiorem celów nie do końca

elektrycznej lub wszelkich innych podstawowych zasobów naturalnych, których rezultatem jest zagrożenie życia ludzkiego, a także 9. grożenie popełnieniem wymienionych czynów. 
sprecyzowanych"22. Regulacja ta nie kreuje zatem nowego typu czynu zabronionego, lecz jedynie dodatkowo charakteryzuje szczególną treścią strony podmiotowej bardzo szeroką grupę przestępstw uregulowanych w kodeksie karnym ${ }^{23}$ i poza nim. Pojęcie przestępstwa terrorystycznego nie jest więc kategorią jednostkową, lecz zbiorczą. W tym kontekście pojęcie ,przestępstwa o charakterze terrorystycznym”, a zwłaszcza „przestępstwa terrorystycznego" może być więc postrzegane jako pewnego rodzaju metafora czy też skrót myślowy, nie zaś jako typ przestępstwa w tradycyjnym znaczeniu, charakteryzujący się określonym w przepisie szczególnym zespołem znamion. W tle przyjętej w art. $115 \S 20$ k.k. definicji ustawowej bardziej zasadne zatem zdaje się mówienie raczej o „przestępczości o charakterze terrorystycznym” — analogicznie jak choćby o „przestępczości zorganizowanej” czy „przestępczości zawodowej" lub ,powrotnej” - niż o przestępstwie o takim charakterze. $\mathrm{Z}$ całą pewnością chodzi bowiem w tym wypadku o rodzaj, a nie o typ przestępstwa. Przestępstwo o charakterze terrorystycznym jako kategoria pojęciowa znajduje się więc na tym samym poziomie znaczeniowym co ,przestępstwo powrotne”, „przestępstwo chuligańskie” czy „,przestępstwo zorganizowane", jako pewne kategorie zbiorcze i umowne zarazem, obejmujące określoną klasę przestępnych zachowań, wyodrębnionych ze względu na ich szczególne właściwości przedmiotowe i podmiotowe, wskazane w ustawie. Stwierdzenie to pozostaje w związku z funkcją tej regulacji. Stanowi ona wszakże podstawę nadzwyczajnego obostrzenia kary, analogicznie jak zorganizowane, zawodowe czy powrotne formy przestępnego zachowania, nie kreuje natomiast „przestępstwa”. Pojęcie to łączone jest bowiem bądź to z przestępstwem jako pojęciem ogólnym, bądź też z typem czynu zabronionego, bądź wreszcie ze zdarzeniem indywidualno-konkretnym. Regulacja art. $115 \S 20$ k.k. tworzy tymczasem kategorię o innym charakterze, integrującą typ czy raczej typy czynu zabronionego ze szczególnym celem. Nie powstaje więc nowy typ prze-

${ }^{22}$ K. Indecki, W sprawie definicji normatywnej terroryzmu, [w:] Przestępczość zorganizowana, świadek koronny, terroryzm w ujęciu praktycznym, red. E.W. Pływaczewski, Kraków 2005, s. 290.

${ }^{23}$ W samym kodeksie karnym z 1997 r. formalny wymóg minimalnego ustawowego zagrożenia karą na poziomie 5 lat pozbawienia wolności spełnia około 250 typów czynów zabronionych. 
stępstwa, a jedynie typy istniejące w ustawie karnej zostają wzbogacone o specyfikujące je na tle danej kategorii zachowań „psychiczne nastawienie" sprawcy. Jak trafnie w tym kontekście zwraca uwagę Agnieszka Rybak-Starczak, w konsekwencji przestępstwa objęte regulacją art. 115 $\S 20$ k.k., popełnione w warunkach w nim określonych, przestają być celem sprawcy, a stają się jedynie środkiem do osiągnięcia jednego $\mathrm{z}$ celów wymienionych $\mathrm{w}$ tym przepisie ${ }^{24}$. Charakter terrorystyczny zachowania wynika jedynie ze szczególnej treści zamiaru sprawcy, która w normatywnej formule art. $115 \S 20$ k.k. stanowi subiektywny czynnik stymulujący sprawców bardzo licznej grupy przestępstw o relatywnie wysokim stopniu społecznej szkodliwości, określonych zarówno w kodeksie karnym, jak i poza nim. W ustawie została ona wyciągnięta przed nawias, tworząc rodzaj „multitypu”, którego naganność wzrasta właśnie ze względu na towarzyszące sprawcy „nastawienie terrorystyczne”. Norma sankcjonowana „przestępstwa o charakterze terrorystycznym” stanowi tym samym kategorię integrującą normę zakazującą realizacji jednego z celów określonych $\mathrm{w}$ art. $115 \S 20$ k.k. oraz normę wynikającą z dyspozycji typu czynu zabronionego, którego popełnienie lub groźba popełnienia ma służyć ich realizacji ${ }^{25}$. Wspólnym mianownikiem powstałego w ten sposób konglomeratu jest nowa kategoria dóbr prawnych w szczególny sposób chronionych. Z logicznego punktu widzenia, jak zauważa Cezariusz Sońta, zabieg ten prowadzi do powstania dychotomii w podziale przestępstw zagrożonych karą co najmniej 5 lat pozbawienia wolności, wśród których można wyróżnić „,przestępstwa o charakterze terrorystycznym" oraz niemające takiego charakteru inne przestępstwa — „przestępstwa pospolite”. Wśród czynów identycznych od strony przedmiotowej jedne mogą mieć więc charakter terrorystyczny, inne z racji treści strony podmiotowej — właściwości takiej mieć nie będą ${ }^{26}$. Jedną z konsekwencji takiego stanu rzeczy jest to, iż bardzo utrudnione, a wręcz niemożliwe staje się precyzyjne $\mathrm{i}$ jednoznaczne oddanie specyfiki terrorystycznego charakteru przestępstwa w kwalifikacji praw-

24 A. Rybak-Starczak, Środek do osiagnięcia celu, „Rzeczpospolita” 4 listopada 2004 r.

25 Por. R. Zawłocki, [w:] Kodeks karny. Część ogólna. Komentarz do artykułów 32 116, t. 2, red. M. Królikowski, R. Zawłocki, Warszawa 2011, s. 1162 n.

${ }^{26}$ C. Sońta, op. cit., s. 15. 
nej ${ }^{27}$. Terrorystyczny charakter przestępstwa można więc wykazywać i wskazywać jedynie w opisie czynu przypisanego sprawcy ${ }^{28}$. W świetle poczynionych uwag bezsporne jest to, iż podstawy skazania nie może w szczególności stanowić przepis art. 115 § 20 k.k., jako jedyny przepis określający przypisane sprawcy przestępstwo terrorystyczne. Niezbędne jest zatem ustalenie, znamiona jakiego typu przestępstwa sprawca w warunkach terrorystycznych wyczerpał, ten przepis będzie bowiem podstawowym elementem kwalifikacji prawnej ${ }^{29}$. De lege lata brak także możliwości posłużenia się złożonym opisem podstawy skazania, który w kwalifikacji prawnej uwzględniałby, poza przepisem określającym typ czynu zabronionego, którego sprawca się dopuścił, również art. 115 $\S 20$ k.k., w warunkach którego do popełnienia tego czynu doszło, co pozwoliłoby na oddanie różnic między terrorystycznym a nieterrorystycznym wyczerpaniem znamion przestępstw objętych formalnym warunkiem minimalnego progu zagrożenia karą 5 lat pozbawienia wolności. Funkcją art. $115 \S 20$ k.k. jest bowiem jedynie definiowanie w warunkach wykładni autentycznej pewnej ogólnej kategorii pojęciowej, mającej normatywne znaczenie zwłaszcza dla wymiaru kary, nie zaś dookreślanie charakteru konkretnego czynu zabronionego w kwalifikacji prawnej ${ }^{30}$.

27 Por. R. Zgorzały, Przestępstwo o charakterze terrorystycznym w polskim prawie karnym, „Prokuratura i Prawo” 2007, nr 7-8, s. 58 i 67. Chodzi rzecz jasna o przestępstwa stricte terrorystyczne, których znamiona nie odwołują się wprost do „terrorystycznego rysu" zamachu. Odmiennie sytuacja przedstawia się bowiem w przypadku tzw. przestępstw okołoterrorystycznych popełnianych „na przedpolu” przestępstwa o charakterze terrorystycznym, w których „terrorystyczny kontekst” eksponowany jest expressis verbis w ich znamionach. Kwalifikacja zachowania sprawcy ujawni zatem jego „terrorystyczny kontekst" w przypadku przypisania między innymi przestępstw stypizowanych w art. 165a k.k. (finansowanie przestępstwa o charakterze terrorystycznym), art. 255a k.k. (rozpowszechnianie treści mających ułatwić popełnienie przestępstwa o charakterze terrorystycznym) czy art. $258 \S 2$ i 4 k.k. (udział, zakładanie lub kierowanie grupą lub związkiem o charakterze terrorystycznym).

${ }^{28}$ Por. R. Zawłocki, op. cit., s. 1163.

29 A. Michalska-Warias, [w:] Kodeks karny. Komentarz, red. T. Bojarski, Warszawa 2016, s. 325.

30 Przepisu tego nie można więc uwzględnić w kwalifikacji prawnej analogicznie — przykładowo, jak nie uwzględnia się w charakterystyce podstawy skazania za znęcanie się nad osobą najbliższą (art. 207 § 1 k.k.) art. 115 § 11 k.k. czy też jak w kwalifikacji prowadzenia pojazdu mechanicznego w stanie nietrzeźwości (art. 178a k.k.) nie uwzględ- 
Przepis ten, jak wcześniej podkreślono, nie typizuje wszakże nowego, autonomicznego czynu zabronionego, lecz jedynie wskazuje na poziomie ogólnym szczególnie naganne i przez to bardziej karygodne „nastawienie sprawcy". Nie może więc być on użyty ani w kumulatywnej podstawie skazania uwzględniającej i oddającej relację krzyżowania się zakresów znamion typów czynów zabronionych, które sprawca jednym czynem wyczerpał (art. $11 \S 2$ k.k.), ani jako przepis w inny sposób dookreślający w złożonej kwalifikacji terrorystyczny charakter popełnionego czynu ${ }^{31}$. Nie jest to zresztą przypadek ani odosobniony, ani nowy. Analogiczna sytuacja powstaje $\mathrm{w}$ razie dopuszczenia się przez sprawcę występku o charakterze chuligańskim. Także przypisując sprawcy czynu zabronionego jego „chuligańskość”, specyficznych, zwiększających naganność konkretnego zachowania treści przedmiotowych oraz podmiotowych nie można wskazać w podstawie skazania, odwołując się do definicji ustawowej z art. $115 \S 21$ k.k. Należy zwrócić uwagę, iż w podstawie skazania za występek o charakterze chuligańskim, jak wskazuje się w dogmatyce i orzecznictwie, w warunkach kwalifikacji złożonej, przywołuje się przepis odnoszący się, w rzeczy samej, wyłącznie do szczególnej zasady wymiaru kary (art. 57a § 1 k.k., pod rządami kodeksu karnego z 1969 roku — art. $59 \S 1)^{32}$. Przepis ten, co nie powinno budzić wątpliwości, nie odnosi się jednak do znamion typu czynu zabronionego, określa bowiem jedynie następstwa, a nie istotę takiego zachowania. Zasadnie można by zatem także przyjąć, iż jego pominięcie w charakterystyce podstawy skazania, z dogmatycznego punktu widzenia, nie byłoby błędem. Nie można w tym kontekście tracić z pola widzenia podstawowej funkcji, jaką pełnią instytucje objęte legalnymi definicjami art. 115 § 20 i 21 k.k. Zostały

nia się przepisu art. $115 \S 16$ k.k., który ten stan definiuje. Funkcja definicji legalnych aktualizuje się bowiem na innym poziomie ustawowej charakterystyki niż kwalifikacja prawna konkretnego czynu zabronionego.

31 Odmiennie w kwestii możliwości posłużenia się w złożonej podstawie skazania za przestępstwo o charakterze terrorystycznym art. $115 \S 20$ k.k.: T. Przesławski, [w:] Kodeks karny. Komentarz, red. R.A. Stefański, Warszawa 2017, s. 164-165; por. także C. Sońta, op. cit., s. 17.

32 Por. wyrok SN z 30 kwietnia 1996 r., WR 49/96, OSNKW 1996, nr 9-10, poz. 73; tak też W. Wróbel, [w:] Kodeks karny. Czesść ogólna. Komentarz, t.1, red. A. Zoll, Warszawa 2007, s. 724; P. Daniluk, [w:] Kodeks karny. Komentarz, red. R.A. Stefański, s. 778 . 
one bowiem przez ustawodawcę uznane za okoliczności wpływające na wymiar kary, ściślej, jej nadzwyczajną modyfikację, nie zaś za znamiona typu czynu zabronionego, a zważywszy na charakter tych okoliczności — typu kwalifikowanego. Ich zasadniczym miejscem zatem — i w tym zakresie są absolutnie nieodzowne — jest podstawa wymiaru kary. Abstrahując od dogmatycznej zasadności przywoływania w podstawie skazania za występek chuligański art. 57a k.k. — choć dostrzegając jego walory zwłaszcza w kontekście wymogu jak najpełniejszego oddania w kwalifikacji prawnej charakteru przypisanego sprawcy czynu - trzeba podkreślić, iż ani w piśmiennictwie, ani na gruncie orzecznictwa jako element złożonej podstawy skazania w przypadku występku chuligańskiego nigdy nie był brany pod uwagę art. $115 \S 21$ k.k. (pod rządami kodeksu karnego z 1969 roku — art. 120 § 14). Jeśli iść tym tropem, w przypadku określania podstawy skazania za przestępstwo terrorystyczne, per analogiam bardziej zasadne, bo mieszczące się w dotychczasowej praktyce i tradycji kwalifikacji, jest zatem przywołanie w podstawie skazania art. $65 \S 1$ k.k., względnie art. $65 \S 1$ w zw. z art. $64 \S 2$ k.k. ${ }^{33}$ Tak złożona kwalifikacja prawna dookreśla bowiem wagę przypisanego sprawcy czynu, sytuując go w kręgu najcięższych form przestępczości. Nie można jednak tracić z pola widzenia, iż satysfakcja związana z przyjęciem takiego rozwiązania może być jedynie częściowa. Przepis art. 65 $\S 1$ k.k. odnosi się bowiem nie tylko do przestępstwa terrorystycznego, lecz także do innych form szczególnie niebezpiecznej przestępczości. W oderwaniu od opisu czynu jego umieszczenie w podstawie skazania nie jest więc w stanie wprost i w sposób jednoznaczny oddać charakte-

${ }^{33} \mathrm{~W}$ kontekście zasygnalizowanej wątpliwości należy się zgodzić z poglądem wyrażonym przez J. Lachowskiego, według którego w kwalifikacji prawnej może być powołany wyłącznie art. $65 \S 1$ k.k., nie jest natomiast potrzebne przywoływanie art. 64 $\S 2$ k.k., przepis ten określa bowiem jedynie regułę nadzwyczajnego wymiaru kary i jako taki, łącznie z art. $65 \S 1$ k.k., powinien znaleźć się w podstawie wymiaru kary. J. Lachowski, [w:] V. Konarska-Wrzosek, Kodeks karny. Komentarz, Warszawa 2016, s. 395; por. J. Majewski, [w:] Kodeks karny. Część ogólna. Komentarz, t. 1, red. A. Zoll, s. 822; W. Zalewski, [w:] Kodeks karny. Część ogólna, t. 2, red. M. Królikowski, R. Zawłocki, Warszawa 2015, s. 458; A. Sakowicz, [w:] Kodeks karny. Część ogólna, t. 2, red. M. Królikowski, R. Zawłocki, Warszawa 2011, s. 65; W. Zalewski, [w:] Kodeks karny. Komentarz, red. R.A. Stefański, s. 495. Por. także wyrok SA w Katowicach z 30 października 2008 r., II AKa 266/08, LEX 477535. 
ru terrorystycznego przestępstwa. Bez warstwy opisowej wskazuje on bowiem jedynie na grupę okoliczności obciążających sprawcę popełnionego przestępstwa. W tym stanie rzeczy, wobec sygnalizowanego w literaturze przedmiotu postulatu dotyczącego potrzeby precyzyjniejszego oddania charakteru terrorystycznego w kwalifikacji prawnej przypisanego sprawcy czynu ${ }^{34}$, pod rozwagę można by wziąc — przy zachowaniu status quo w sposobie ustawowej charakterystyki przestępstwa terrorystycznego, przyjętej w art. $115 \S 20$ k.k. — wprowadzenie do przepisów części ogólnej - analogicznie jak choćby w przypadku czynu ciągłego $\mathrm{z}$ art. 12 k.k., stanowiącego rodzaj uniwersalnej klauzuli pozwalającej na oddanie w kwalifikacji prawnej powtarzalności zachowań sprawcy, podejmowanych w szczególnych warunkach strony podmiotowej i przedmiotowej - przepisu odnoszącego się stricte do zachowań o charakterze terrorystycznym, który mógłby być wówczas uwzględniany w kwalifikacji prawnej jako przepis ściśle dookreślający tę kategorię zachowań ${ }^{35}$. Co do zasady jednak dyskusyjne ze względu na obecną ustawową funkcję omawianej okoliczności wydaje się uzasadnienie takiego kierunku modyfikacji przepisów kodeksowych.

\title{
Remarks on the essence of a terrorist crime and penalty for it. Part I
}

\author{
Summary
}

The study attempts to draw attention to some, the most important complex threads - both in the criminological and the dogmatic legal sense - problems of crime of terrorist character. The starting point of considerations conducted in part I of the article is the historical analysis referring to genesis and evolution of dogmatic and normative perception and understanding of the concept of terrorist offense - from the legislation of the interwar period through post-war regulations, until the regulation of the Penal Code of 1969. The central thread of this part of the study is the analysis of the normative shape of a terrorist offense construction in terms of art. $115 \S 20$ of the Penal Code, legal nature of this institution as well as the consequences at the level of application of the discussed regulations. Considerations taken in part II of the study cover issues regarding the consequences of committing a crime of a terrorist character in the sphere of statu-

${ }^{34}$ Por. R. Zgorzały, op. cit., s. 59.

35 Por. ibidem, s. 58 i 67; R. Kokot, op. cit. 
tory and judicial punishment and other penal measures. In this part of the analysis, the issue of extraordinary tightening of punishment was subjected in particular to a terrorist crime including doubts that in practice the provisions relating to the rule of progression of punishment of terrorists can cause, as well as the possibility and rules of using other institutions shaping the legal situation of the perpetrator of a terrorist offense.

Keywords: crime, terrorism, terrorist purpose, terrorist attack, framework directive, extraordinary tightening of punishment. 